\title{
Vermicompost leachate reduces some negative effects of salt stress in pomegranate
}

\author{
Siamak Shirani Bidabadi ${ }^{1} \cdot$ Safoora Dehghanipoodeh $^{2} \cdot$ Glenn C. Wright $^{3}$
}

Received: 14 February 2017/ Accepted: 2 August 2017/Published online: 9 August 2017

(C) The Author(s) 2017. This article is an open access publication

\begin{abstract}
Purpose Growth and productivity of plant crops are negatively affected by salt stress. Vermicompost leachate (VCL) has beneficial effects on plant growth in several different ways. This experiment was conducted to investigate the potential of VCL for raising the tolerance of pomegranate against salinity.

Methods A pot experiment was organized to analyze some physiological attributes and antioxidant activities of two Iranian pomegranate cultivars under different concentrations of $\mathrm{NaCl}$ with or without VCL.

Results Salinity negatively affected the growth properties of pomegranate, while foliar spray of VCL-induced salt tolerance by reducing the accumulation of $\mathrm{Na}^{+}$in the seedlings. Leaf area and shoot and root fresh and dry weight of VCL-treated pomegranate plants showed a significant increase regardless of whether the seedling growth was under non-saline or saline conditions. Chlorophyll loss and reduced photosynthesis efficiency caused by salinity were also ameliorated using VCL. Foliar application of
\end{abstract}

Siamak Shirani Bidabadi

siamakshirani.upm@gmail.com

Safoora Dehghanipoodeh

safoora.dehghanipoodeh@yahoo.com

Glenn C. Wright

gwright@ag.arizona.edu

1 Department of Horticulture, College of Agriculture, Isfahan University of Technology, IUT, Isfahan 84156-83111, Iran

2 Department of Horticultural Science, College of Agriculture and Natural Resources, University of Tehran, Karaj, Iran

3 The School of Plant Sciences, College of Agriculture and Life Sciences, University of Arizona, Tucson, AZ 85364, USA
VCL also improved the activity of antioxidant enzymes and caused a reduction in oxidative stress and electrolyte leakage.

Conclusions These results suggested that VCL could alleviate the damage caused by salt stress in pomegranate by limiting the agglomeration of $\mathrm{Na}^{+}$and amending the activities of antioxidant enzymes by which the efficiency of plant increases.

Keywords Antioxidant activities · Fruit crops · Organic wastes · Photosynthesis efficiency $\cdot$ Salinity $\cdot$ Seedlings . Sodium accumulation

\section{Introduction}

Growth and productivity of crops are negatively affected by salt stress. The entry of high amounts of salt in the soil and irrigation water disrupts all physiological and biochemical processes in the plant (Hasanuzzamaan et al. 2013). The reduced osmotic potential of soil solution, imbalance in nutritional elements, and the effect of ion toxicity are consequences of salinity which has a detrimental effect on the growth of plants (Ashraf 1994; Parvaiz and Satyawati 2008). During the onset and spread of salt stress in the plant, all physiological and biochemical processes of the plant are affected. (Parvaiz and Satyawati 2008). However, the negative effects of salt stress on plants depend on the severity and exposure time of salinity. Plant genotypes and environmental factors also play a decisive role; therefore, finding a suitable moderator or stress relievers is one of the duties of researchers (Hasanuzzamaan et al. 2013). Due to the high cost and hazardous effects of chemical fertilizers, using organic compound solutions as foliar fertilizer sprays is developing. Moreover, restricted nutrient supply and 
restriction in chemical fertilizer use in saline soils are considerable problems that should be solved by proper methods and efficient management practices (Astaraei and Ivani 2008; Chinsamy et al. 2013). Organic fertilizers improve soil structure and enhance nutrient availability, thus helping to protect the yield and quality, and are more affordable than synthetic fertilizers (Ayyobi et al. 2014). Use of organic sources of nutrients improves the soil health by sustaining the balance of organic matter, thereby helping to amend physical, chemical, and biological properties of the soil (Mir et al. 2013). Vermicomposts, which are created by crushing organic wastes from earthworm, contain nutrients in a form that is easily absorbed by the plant. Vermicompost leachate (VCL) is a liquid phase that comes from vermicompost and it has a very positive impact on soil improvement and plant growth (Chinsamy et al. 2013). Previous reports have shown that vermicompost modulates the harmful effects of salinity stress on several plant crops (Atiyeh et al. 2000; Oliva et al. 2008; Sallaku et al. 2009; Nandi et al. 2013; Ayyobi et al. 2014). Beneficial effects of vermicompost leachate have also been reported in bulbous plants and some commercially important crops such as banana and tomato (Aremu et al. 2012; Arthur et al. 2012; Aremu et al. 2014). Pomegranate (Punica granatum) is a strategic horticultural crop cultivated all over the world (Mirzapour and Khoshgoftarmanesh 2013). It is one of the oldest fruit crops which has been cultivated since ancient times for its economic, ornamental, and medicinal properties (Pirseyedi et al. 2010; Ramezanian et al. 2009). Leaves, fruits, and bark of the pomegranate tree are used in the traditional medicine (Hulya Orak 2009). Fruits are a rich source of minerals and sugars, along with vitamin $\mathrm{C}$ and certain phenolic compounds which act as natural antioxidants (Zaouaya et al. 2012). The origin of pomegranate is arid and semi-arid regions of Iran, where in seriously affected by high salinity (Okhovatian-Ardakani et al. 2010). Pomegranate trees are moderately salt tolerant under field conditions (El-Khawaga et al. 2013). Hence, an attempt has been made to examine the interactive effects of salinity and vermicompost leachate on growth indices, physiological parameters, and antioxidative enzyme activities of two commercial cultivars of pomegranate. This work was, therefore, aimed to assess the efficiency of foliar application of VCL to mitigate the negative effects of salinity on pomegranate growth and productivity.

\section{Materials and methods}

\section{Plant material and growing conditions}

Seed extraction and germination was achieved according to the method recommended by Rawat et al. (2010). Ripe fruits of Punica granatum cultivars "Rabab" and "Malas
Daneh Ghermez" were harvested in the month of August 2013. Then, their seeds were collected and dried in the shade. Afterwards, the imbibed seeds were placed between layers of moist peat moss and exposed to chilling $\left(5^{\circ} \mathrm{C}\right)$ for up to 30 days. Following germination under greenhouse conditions, 60-day-old seedlings were transplanted into black plastic pots $10 \mathrm{~cm}$ in diameter (one plant per pot) filled with soil garden having loamy texture, $\mathrm{pH} 7.8$, with an EC of $1.7 \mathrm{ds} \mathrm{cm}^{-1}$, perlite, and sand with a ratio of $2: 1: 1$, respectively, and grown under glasshouse conditions. Plants were irrigated and fertilized with a complete floral fertilizer 20-20-20 (a product of CIFO S.P.A., Bologna, Italy.), to promote strong growth until 30 July 2014, when salinity and VCL treatments were imposed (seedlings were $30-40 \mathrm{~cm}$ in height).

\section{Treatments and experimental design}

On 1 August 2014, 36 pomegranate seedlings that were used for the experiment were arranged in a completely randomized factorial design of six treatments with three singleseedling replications along a glasshouse bench under $28{ }^{\circ} \mathrm{C}$ daytime and $18{ }^{\circ} \mathrm{C}$ nighttime greenhouse temperatures and $250 \mu \mathrm{molm}^{-2} \mathrm{~S}^{-1}$ light intensity. The salinity of the irrigation water was 0,30 , and $60-\mathrm{mM} \mathrm{NaCl}$. Eighteen plants, 12 of each cultivar, received each salinity treatment. $\mathrm{NaCl}$ treatments started in 1-year-old seedlings. Plants were irrigated with $1 \mathrm{~L}$ of salt solution as needed and leached with tap water, after every fourth irrigation to prevent salt accumulation. Salt treatments were continued for 3 months, and plants were destructively harvested on 1 November 2014. VCL treatment was applied along with saline treatments, beginning on 1 August 2014 using VCL as spray and tap water as a control. A hand sprayer was used to apply VCL to run off. Seedlings that were grown under normal or saline conditions sprayed with VCL and tap water.

\section{VCL preparation and specification}

Vermicompost (VC) and vermicompost leachate (VCL) were prepared according to the approach of Ayyobi et al. (2014). Vermicompost was processed by Earthworms (Eisenia fetida) in proportion to $25 \mathrm{~g}$ of earthworms per $1 \mathrm{~kg}$ of cow manure for 2 months. The amount of $50 \mathrm{~kg}$ of obtaining vermicompost was squeezed by adding $25 \mathrm{~L}$ of water and allowed the leachate to be extracted for $48 \mathrm{~h}$ and then gathered in a tank. Table 1 shows the characteristics of VCL derived from cow manure.

\section{Analysis of growth parameters}

Leaf area was measured in $\mathrm{cm}^{2}$ using a leaf area meter (WinArea- UT- 11, Iran). After washing the plants for the 
separation of mud and other foreign particles sticking to the plants, fresh mass of shoots and roots was recorded. The shoots and the roots were then dried in an oven at $80^{\circ} \mathrm{C}$ for $48 \mathrm{~h}$ to specify a fixed dry weight. The leaves were collected and frozen in liquid nitrogen and kept at $-80{ }^{\circ} \mathrm{C}$ until used for biochemical and physiological measurements.

\section{Chlorophyll fluorescence, chlorophyll, and proline measurements}

Chlorophyll fluorescence (Fv/Fm) was measured applying a fluorometer (Walz, Effeltrich, Germany). The chlorophyll content was measured with a portable leaf chlorophyll meter (SPAD 502, Minolta Co., Osaka, Japan). The proline content was measured according to the method of Bates et al. (1973).

Determination of endogenous $\mathrm{MDA}$ and $\mathrm{H}_{2} \mathrm{O}_{2}$ concentrations and electrolyte leakage (EL) of pomegranate leaves

Lipid peroxidation indicated by accumulated malondialdehyde (MDA) was assessed according to Wang et al. (2009). After recording the absorbances of the supernatant at 450-, 532-, and 600-nm wavelengths, MDA content was calculated on a fresh weight basis using the following formula:

$\left(\mathrm{nmol} \mathrm{MDA} \mathrm{g}{ }^{-1} \mathrm{FW}\right)=6.45\left(\mathrm{OD}_{532}-\mathrm{OD}_{600}\right)-0.56\left(\mathrm{OD}_{450}\right)$ $\times 1000$.

Hydrogen peroxide $\left(\mathrm{H}_{2} \mathrm{O}_{2}\right)$ was measured according to method of Velikova and Loreto (2005). Electrolyte leakage (EL) was measured by applying a conductivity meter according to Ozden et al. (2009).

Table 1 Characteristic of vermicompost leachate obtained from cattle manure

\begin{tabular}{ll}
\hline Characteristic & Vermicompost leachate \\
\hline $\mathrm{pH}$ & 7.56 \\
Electrical conductivity $\left(\mathrm{ds} \mathrm{m}^{-1}\right)$ & 5.42 \\
$\mathrm{~N}(\%)$ & 1.3 \\
$\mathrm{P}_{2} \mathrm{O}_{5}(\%)$ & 0.7 \\
$\mathrm{~K}_{2} \mathrm{O}(\%)$ & 0.9 \\
$\mathrm{Cu}(\%)$ & 0.05 \\
$\mathrm{Zn}(\%)$ & 0.09 \\
$\mathrm{Mn}(\%)$ & 0.18 \\
\hline
\end{tabular}

These values are subjected to variations depending on the cattle feeding
Determination of sodium $\left(\mathrm{Na}^{+}\right)$concentration

For measurement of $\mathrm{Na}^{+}$concentration, the leaf samples were dried in $60{ }^{\circ} \mathrm{C}$ for $48 \mathrm{~h}$. Then, $1 \mathrm{~g}$ of leaves was ground using an electric grinder and scorched in $560{ }^{\circ} \mathrm{C}$. The obtained ashes were digested in $10 \mathrm{ml}$ of $1 \mathrm{~N} \mathrm{HCl}$. Then, the concentration of $\mathrm{Na}^{+}$in the digested samples was determined using a flame photometer (Model CL 378, Nanolytik, Germany).

\section{Enzyme extractions and assays}

Three months after salinity and VCL treatments, the fresh leaves were collected and enzyme activities were assayed. The samples were prepared as described by Azooz et al. (2012) for CAT (catalase): APX (ascorbate peroxidase) and SOD (superoxide dismutase) activity assay. The activity of SOD was estimated by recording the decrease in absorbance of superoxide-nitroblue tetrazolium complex by the enzyme (Cavalcanti et al. 2004). In addition, then, one SOD unit was defined as the amount of enzyme required to inhibit 50\% of the NBT photo-reduction compared to the tubes without the plant extract and expressed as a unit of enzyme activity per mg of protein. Catalase (CAT) activity was measured according to Aebi (1984). The decrease of $\mathrm{H}_{2} \mathrm{O}_{2}$ was monitored at $240 \mathrm{~nm}$ and quantified by its molar extinction coefficient $\left(36 \mathrm{M}^{-1} \mathrm{~cm}^{-1}\right)$ and the results expressed as CAT units per mg of leaf fresh weight.

Ascorbate peroxidase (APX) activity was determined by the method of Nakano and Asada (1981). One unit of APX activity was defined as 1-M ascorbate oxidized per minute at $290 \mathrm{~nm}$ and the specific activity was expressed as $\mathrm{U} \mathrm{mg}^{-1}$ protein.

The statistical procedure was performed by SAS 9.1 and means were compared with the LSD multiple range test.

\section{Results and discussion}

Effect of foliar application of VCL on leaf area, fresh and dry weight of shoots and roots of pomegranate seedlings under different $\mathrm{NaCl}$ levels is presented in Table 2. Leaf area, fresh and dry weight of shoots and roots of both cultivars were significantly reduced by increasing salinity, whereas in cultivar Rabab, leaf area, fresh and dry weight of shoots and roots were reduced by $32.86,37.48,50.19$, 53.33, and 50.97\%, respectively, while in the Malas Daneh Ghermez cultivar, leaf area, fresh and dry weight of shoots and roots were reduced by 46.90, 37.80, 49.34, 50.92, and $52.13 \%$, respectively, at the highest salinity level $(60 \mathrm{mM} \mathrm{NaCl})$ in comparison with non-saline controls (Table 2). The negative impacts of salinity on the plants growth have been reported by many researchers (Parvaiz 
Table 2 Effects of VCL treatments on shoot fresh and dry weight, root, fresh and dry weight and leaf area of pomegranate seedlings under $\mathrm{NaCl}$-induced salt stress

\begin{tabular}{|c|c|c|c|c|c|c|c|}
\hline Cult. & $\begin{array}{l}\mathrm{VCL} \\
\text { treatment }\end{array}$ & $\begin{array}{l}\text { Salinity } \\
(\mathrm{mM})\end{array}$ & $\begin{array}{l}\text { Shoot fresh } \\
\text { weight }(\mathrm{g})\end{array}$ & $\begin{array}{l}\text { Shoot dry } \\
\text { weight (g) }\end{array}$ & $\begin{array}{l}\text { Leaf area } \\
\left(\mathrm{cm}^{2}\right)\end{array}$ & $\begin{array}{l}\text { Root fresh } \\
\text { weight (g) }\end{array}$ & $\begin{array}{l}\text { Root dry weight } \\
\text { (g) }\end{array}$ \\
\hline \multirow[t]{6}{*}{ "Rabab" } & \multirow[t]{3}{*}{ Treated } & 0 & $5.84 \pm 0.18^{\mathrm{a}}$ & $2.84 \pm 0.07^{\mathrm{a}}$ & $2.84 \pm 0.07^{\mathrm{a}}$ & $2.93 \pm 0.22^{\mathrm{a}}$ & $1.62 \pm 0.33^{\mathrm{a}}$ \\
\hline & & 30 & $4.90 \pm 0.17^{\mathrm{bc}}$ & $2.44 \pm 0.11^{\mathrm{bc}}$ & $2.58 \pm 0.11^{\mathrm{ab}}$ & $2.15 \pm 0.21^{\mathrm{b}}$ & $1.47 \pm 0.33^{\mathrm{a}}$ \\
\hline & & 60 & $3.80 \pm 0.10^{\mathrm{de}}$ & $2.01 \pm 0.16^{\mathrm{d}}$ & $2.30 \pm 0.07^{\mathrm{cd}}$ & $1.86 \pm 0.20^{\mathrm{c}}$ & $1.19 \pm 0.06^{\mathrm{b}}$ \\
\hline & \multirow[t]{3}{*}{ Untreated } & 0 & $5.63 \pm 0.37^{\mathrm{a}}$ & $2.65 \pm 0.18^{\mathrm{b}}$ & $2.80 \pm 0.10^{\mathrm{a}}$ & $2.85 \pm 0.10^{\mathrm{a}}$ & $1.55 \pm 0.08^{\mathrm{a}}$ \\
\hline & & 30 & $4.06 \pm 0.14^{\mathrm{d}}$ & $1.91 \pm .013^{\mathrm{d}}$ & $2.21 \pm 0.10^{\mathrm{d}}$ & $1.64 \pm 0.15^{\mathrm{c}}$ & $1.16 \pm 0.09^{\mathrm{b}}$ \\
\hline & & 60 & $3.52 \pm 0.18^{\mathrm{ef}}$ & $1.32 \pm 0.08^{\mathrm{f}}$ & $1.88 \pm 0.08^{\mathrm{e}}$ & $1.33 \pm 0.12^{\mathrm{d}}$ & $0.76 \pm 0.06^{\mathrm{cd}}$ \\
\hline \multirow{7}{*}{$\begin{array}{l}\text { "Malas Daneh } \\
\text { Ghermez" }\end{array}$} & \multirow[t]{3}{*}{ Treated } & 0 & $5.17 \pm 0.33^{\mathrm{b}}$ & $2.37 \pm 0.18^{\mathrm{bc}}$ & $2.51 \pm 0.39^{\mathrm{bc}}$ & $2.27 \pm 0.14^{\mathrm{b}}$ & $0.99 \pm 0.19^{\mathrm{bc}}$ \\
\hline & & 30 & $4.67 \pm 0.14^{\mathrm{c}}$ & $1.99 \pm 013^{\mathrm{d}}$ & $2.50 \pm 0.12^{\mathrm{bc}}$ & $1.84 \pm 0.09^{\mathrm{c}}$ & $0.74 \pm 012^{\mathrm{cd}}$ \\
\hline & & 60 & $3.29 \pm 0.17^{\mathrm{fg}}$ & $1.55 \pm 0.13^{\mathrm{e}}$ & $2.10 \pm 0.20^{\mathrm{de}}$ & $1.28 \pm 0.15^{\mathrm{de}}$ & $0.53 \pm 0.08^{\mathrm{de}}$ \\
\hline & \multirow[t]{3}{*}{ Untreated } & 0 & $4.92 \pm 0.36^{\mathrm{bc}}$ & $2.29 \pm 0.16^{\mathrm{c}}$ & $2.58 \pm 0.16^{\mathrm{ab}}$ & $2.18 \pm 0.14^{\mathrm{b}}$ & $0.94 \pm 0.13^{\mathrm{bc}}$ \\
\hline & & 30 & $3.43 \pm 0.25^{\mathrm{efg}}$ & $1.33 \pm 0.09^{\mathrm{ef}}$ & $2.22 \pm 0.08^{\mathrm{d}}$ & $1.24 \pm 0.06^{\mathrm{de}}$ & $0.60 \pm 0.07^{\mathrm{de}}$ \\
\hline & & 60 & $3.06 \pm 0.22^{\mathrm{g}}$ & $1.16 \pm 0.10^{\mathrm{f}}$ & $1.37 \pm 0.11^{\mathrm{f}}$ & $1.07 \pm 0.11^{\mathrm{e}}$ & $0.45 \pm 0.09^{\mathrm{e}}$ \\
\hline & $\operatorname{LSD}_{(0.05)}$ & & 0.40 & 0.23 & 0.26 & 0.25 & 0.27 \\
\hline
\end{tabular}

Means followed by the same letter are not significantly different by the LSD Multiple Range test at $P \leq 0.05$

and Satyawati 2008; Chinsamy et al. 2013; El-Khawaga et al. 2013 and Hasanuzzamaan et al. 2013). Naeini et al. (2006) reported that pomegranate cuttings tolerate salinity up to $40 \mathrm{Mm}$. Leaf area, fresh and dry weight of shoots and roots of both cultivars were increased by foliar spray of VCL irrespective to the seedling growth under non-saline or saline conditions. In cultivar Rabab treated with VCL, leaf area, fresh and dry weight of shoots and roots increased by $22.34,7.95,52.27,39.85$, and $56.58 \%$, while in VCL-treated Malas Daneh Ghermez cultivar, these attributes were increased 53.28, 7.52, 33.62, 19.62, and $17.78 \%$, respectively, at the highest salinity level $(60 \mathrm{mM} \mathrm{NaCl})$ in comparison with their respective controls (Table 2). Similar results in improving morphological attributes of VCL-treated tomato seedlings such as leaf area and overall aboveground growth were observed in tomato seedlings under a high $\mathrm{NaCl}$-tested concentration $(100 \mathrm{mM})$ (Chinsamy et al. 2013). The lack of sensitivity of all morphological attributes to salinity for VCL-treated seedlings was largely caused by a significant reduction in these attributes for non-VCL-treated seedlings under stressed conditions. The prolonged availability of nutrients during the crop growth provided by the application of enriched vermicomposts might have enhanced the plant growth (Nandi et al. 2013). Ability to high water absorption in vermicompost associated with high amount of macro- and micronutrients results in improving photosynthesis (Fathi et al. 2012). Arthur et al. (2012) reported that the presence of VCL relieved the negative effects caused by shortage of $\mathrm{P}$ and $\mathrm{K}$ during the growth tomato seedlings under nutrient stress. Improvement of plant growth using organic fertilizer such as vermicompost is reported by Ayyobi et al. (2014) in peppermint plants and Nandi et al. (2013) in pomegranate.

For the interaction between the two levels of salinity (30 and $60 \mathrm{mM}$ ) and the two pomegranate cultivars, the best results in terms of morphological characteristics were noticed with cultivar Rabab (Table 2). Accordingly, ElKhawaga et al. (2013) concluded that these differences may be attributed to the various responses of some pomegranate cultivars to environmental conditions. Although the application of $\mathrm{NaCl}$ decreased the content of relative chlorophyll and photosynthesis efficiency of pomegranate seedlings, the foliar application of VCL limited the decreases. VCL increased photosynthesis efficiency in both saline treatments in comparison with the untreated counterparts for both cultivars (Table 3). A reduced amount of chlorophyll and photosynthesis efficiency has also been observed in several species of plants grown in saline conditions (Okhovatian-Ardakani et al. 2010; Hasanpour et al. 2014). Similarly, leaf chlorophyll increased following the application of VCL to tomato seedlings and some bulbous plants under salinity, temperature, water, and nutrient stresses (Chinsamy et al. 2013; Aremu et al. 2014; Chinsamy et al. 2014). VCL may have an important role in alleviating the salinity-induced damage to the chloroplasts by reducing chlorophyllase activity (Chinsamy et al. 2013). Chlorophyll fluorescence provides useful information about primary reactions of photosynthesis and has been widely used in assessing plant responses to environmental stress (Schnabel et al. 1998). Reducing chlorophyll pigments of leaf in response to 
Table 3 Effects of VCL treatments on chlorophyll, photosynthesis efficiency, and proline of pomegranate seedlings under NaCl-induced salt stress

\begin{tabular}{|c|c|c|c|c|c|}
\hline Cult. & VCL treatment & Salinity (mM) & $\begin{array}{l}\text { Relative } \\
\text { chlorophyll }\end{array}$ & $\begin{array}{l}\text { Photosynthesis efficiency (Fv/ } \\
\text { Fm) }\end{array}$ & $\begin{array}{l}\text { Proline } \\
\left(\mu \mathrm{mol} \mathrm{g}{ }^{-1} \mathrm{FW}\right)\end{array}$ \\
\hline \multirow[t]{6}{*}{ "Rabab" } & \multirow[t]{3}{*}{ Treated } & 0 & $13.76 \pm 1.35^{\mathrm{a}}$ & $0.27 \pm 0.04^{\mathrm{a}}$ & $6.69 \pm 0.57^{\text {cde }}$ \\
\hline & & 30 & $11.78 \pm 0.56^{\mathrm{c}}$ & $0.21 \pm 0.02^{\mathrm{b}}$ & $6.90 \pm 0.46^{\mathrm{bcde}}$ \\
\hline & & 60 & $9.39 \pm 0.46^{\mathrm{de}}$ & $0.13 \pm 0.03^{\text {cde }}$ & $8.71 \pm 0.15^{\mathrm{a}}$ \\
\hline & \multirow[t]{3}{*}{ Untreated } & 0 & $13.85 \pm 0.36^{\mathrm{a}}$ & $0.16 \pm 0.04^{\mathrm{c}}$ & $6.76 \pm 0.39^{\text {cde }}$ \\
\hline & & 30 & $10.02 \pm 0.67^{\mathrm{d}}$ & $0.09 \pm 0.02^{\text {efg }}$ & $6.49 \pm 0.50^{\mathrm{de}}$ \\
\hline & & 60 & $7.87 \pm 0.45^{\mathrm{fg}}$ & $0.06 \pm 0.01^{\mathrm{fg}}$ & $6.71 \pm 0.38^{\text {cde }}$ \\
\hline \multirow{7}{*}{$\begin{array}{l}\text { "Ghermez”Malas } \\
\text { Daneh }\end{array}$} & \multirow[t]{3}{*}{ Treated } & 0 & $13.26 \pm 0.85^{\mathrm{ab}}$ & $0.25 \pm 0.04^{\mathrm{ab}}$ & $6.73 \pm 0.65^{\text {cde }}$ \\
\hline & & 30 & $10.30 \pm 0.50^{\mathrm{d}}$ & $0.14 \pm 0.03^{\mathrm{cd}}$ & $6.28 \pm 0.22^{\mathrm{e}}$ \\
\hline & & 60 & $8.17 \pm 0.32^{f}$ & $0.10 \pm 0.02^{\mathrm{def}}$ & $7.00 \pm 0.28^{\mathrm{bcd}}$ \\
\hline & \multirow[t]{3}{*}{ Untreated } & 0 & $12.35 \pm 0.44^{\mathrm{bc}}$ & $0.23 \pm 0.02^{\mathrm{ab}}$ & $6.87 \pm 0.23^{\text {cde }}$ \\
\hline & & 30 & $8.55 \pm 0.82^{\mathrm{ef}}$ & $0.11 \pm 0.02^{\mathrm{de}}$ & $7.17 \pm 0.22^{\mathrm{bc}}$ \\
\hline & & 60 & $6.83 \pm 0.50^{\mathrm{g}}$ & $0.05 \pm 0.02^{\mathrm{g}}$ & $7.55 \pm 0.21^{\mathrm{b}}$ \\
\hline & \multicolumn{2}{|l|}{$\operatorname{LSD}_{(0.05)}$} & 1.12 & 0.05 & 0.65 \\
\hline
\end{tabular}

Means followed by the same letter are not significantly different by the LSD Multiple Range test at $P \leq 0.05$

salinity results in the decline in the values of $\mathrm{Fv} / \mathrm{Fm}$ ratio (Hasanpour et al. 2014). The results of significant reduction in the photosynthetic efficiency $(\mathrm{Fv} / \mathrm{Fm})$ by the higher doses of vermicompost agree with the findings of Lazcano and Dominguez (2010) on the primula plant.

Although VCL-sprayed seedlings of the Malas Dane Ghermez cultivar treated with $60 \mathrm{mM}$ salt had almost similar proline content to untreated counterparts with no significant difference, the highest content of proline was recorded with VCL-treated seedlings of cultivar Rabab under the highest level of $\mathrm{NaCl}(60 \mathrm{mM})$-induced salt stress (Table 3 ). Among other roles, proline acts as an osmolyte under conditions of water deficit and salinityinduced stress and it is recognized as an osmo-protectant compound, stabilizing proteins, inhibiting lipid peroxidation and scavenging of ROS (Garcial et al. 2012). Chinsamy et al. (2013) showed a significant increase in proline concentration in salt-stressed tomato seedlings by VCL treatment. A similar effect was observed with humic acids of vermicompost as reported by Garcial et al. (2012) in rice seedlings under water stress.

The contents of $\mathrm{H}_{2} \mathrm{O}_{2}$ and MDA in pomegranate leaves were strongly affected by both salinity and VCL (Table 4). As expected, salinity increased $\mathrm{H}_{2} \mathrm{O}_{2}$ and MDA contents of the leaves of both cultivars. In Males Dane Ghermez, the content of $\mathrm{H}_{2} \mathrm{O}_{2}$ and MDA was 16.67 and $6.13 \%$ greater than in cultivar Rabab under the highest level of $\mathrm{NaCl}$ (60 Mm) (Table 4). The $\mathrm{H}_{2} \mathrm{O}_{2}$ and MDA contents of VCLtreated seedlings receiving salts were less than those of the untreated seedlings under all levels of $\mathrm{NaCl}$-induced salt stress (Table 4). Clearly, VCL improved the quality of growth, as salt-stressed seedlings showed less foliar necrosis, and less defoliation when treated with VCL. An adaptive mechanism in VCL-treated tomato seedlings reported by Chinsamy et al. (2013) indicates the positive effects of VCL on physiological attributes of plants under salinity. Electrolyte leakage (EL) of leaves in both cultivars increased significantly with increasing levels of NaCl-induced salt stress (Table 4). Malas Daneh Ghermez cultivar showed significantly higher EL $(35.33 \%)$ resulting from the highest level of $\mathrm{NaCl}(60 \mathrm{mM})$-induced salt stress without VCL treatment. Meanwhile, foliar application of VCL caused a reduction in electrolyte leakage when seedlings subjected to salt stress. According to the results of this investigation, under salinity stress, Malas Daneh Ghermez was more sensitive than Rabab.

The $\mathrm{Na}^{+}$concentration of seedlings receiving no vermicompost leachate increased with increasing salinity, as the highest sodium concentration was recorded at $60-\mathrm{mM}$ $\mathrm{NaCl}$ (Table 5). Accumulation of $\mathrm{Na}^{+}$in both cultivars of pomegranate seedlings under salinity and the tendency of Malas Daneh Ghermez to accumulate more $\mathrm{Na}^{+}$than Rabab (Table 5) might partly clarify the apparent greater salt sensitivity of Malas Daneh Ghermez. Naeini et al. (2004) reported that pomegranate accumulates sodium in salt concentrations greater than $40 \mathrm{mM}$. When subjected to increasing salt levels, the seedlings of both cultivars receiving VCL showed a significant decrease in value of $\mathrm{Na}^{+}$compared to the seedlings receiving no VCL and there was no significant difference between two cultivars at 60-mM NaCl (Table 5). Our present results are consistent with the findings of Maie Mohsen et al. (2016) on 
Table 4 Effects of VCL treatments on $\mathrm{H}_{2} \mathrm{O}_{2}$ content, MDA, and EL of pomegranate seedlings under NaCl-induced salt stress

\begin{tabular}{|c|c|c|c|c|c|}
\hline Cult. & VCL treatment & Salinity (mM) & $\mathrm{H}_{2} \mathrm{O}_{2}$ content $\left(\mu \mathrm{mol} \mathrm{g}{ }^{-1} \mathrm{FW}\right)$ & MDA (nmol g $\left.{ }^{-1} \mathrm{FW}\right)$ & EL $(\%)$ \\
\hline \multirow[t]{6}{*}{ "Rabab" } & \multirow[t]{3}{*}{ Treated } & 0 & $20.92 \pm 1.42^{\mathrm{g}}$ & $7.71 \pm 0.63^{\mathrm{f}}$ & $20.33 \pm 1.53^{\mathrm{fg}}$ \\
\hline & & 30 & $24.90 \pm 1.40^{\mathrm{e}}$ & $9.74 \pm 0.35^{\mathrm{e}}$ & $22.67 \pm 1.15^{\mathrm{ef}}$ \\
\hline & & 60 & $29.53 \pm 0.72^{\mathrm{d}}$ & $12.08 \pm 0.35^{\mathrm{c}}$ & $26.33 \pm 0.58^{\mathrm{cd}}$ \\
\hline & \multirow[t]{3}{*}{ Untreated } & 0 & $20.34 \pm 0.69^{\mathrm{g}}$ & $8.02 \pm 0.72^{\mathrm{f}}$ & $22.67 \pm 1.53^{\mathrm{ef}}$ \\
\hline & & 30 & $30.48 \pm 1.18^{\mathrm{d}}$ & $11.18 \pm 0.35^{\mathrm{d}}$ & $28.33 \pm 1.53^{\mathrm{c}}$ \\
\hline & & 60 & $35.76 \pm 0.89^{\mathrm{b}}$ & $13.86 \pm 0.31^{\mathrm{ab}}$ & $32.67 \pm 1.53^{\mathrm{b}}$ \\
\hline \multirow[t]{7}{*}{ "Malas Daneh Ghermez" } & \multirow[t]{3}{*}{ Treated } & 0 & $21.31 \pm 1.36^{\mathrm{fg}}$ & $8.11 \pm 0.81^{\mathrm{f}}$ & $19.33 \pm 1.53^{\mathrm{g}}$ \\
\hline & & 30 & $29.42 \pm 0.73^{\mathrm{d}}$ & $9.67 \pm 0.34^{\mathrm{e}}$ & $24.67 \pm 0.58^{\mathrm{de}}$ \\
\hline & & 60 & $33.10 \pm 0.92^{\mathrm{c}}$ & $13.14 \pm 0.33^{\mathrm{b}}$ & $28.67 \pm 1.53^{\mathrm{c}}$ \\
\hline & \multirow[t]{3}{*}{ Untreated } & 0 & $23.23 \pm 0.47^{\mathrm{ef}}$ & $9.28 \pm 0.48^{\mathrm{e}}$ & $21.00 \pm 2.00^{\mathrm{fg}}$ \\
\hline & & 30 & $37.38 \pm 1.43^{\mathrm{b}}$ & $13.06 \pm 0.73^{\mathrm{b}}$ & $28.33 \pm 1.16^{\mathrm{c}}$ \\
\hline & & 60 & $41.72 \pm 1.81^{\mathrm{a}}$ & $14.71 \pm 0.60^{\mathrm{a}}$ & $35.33 \pm 1.53^{\mathrm{a}}$ \\
\hline & $\operatorname{LSD}_{(0.05)}$ & & 1.94 & 0.89 & 2.37 \\
\hline
\end{tabular}

Means followed by the same letter are not significantly different by the LSD Multiple Range test at $P \leq 0.05$

Table 5 Effects of VCL treatments on $\mathrm{Na}^{+}$content of pomegranate leaf samples under $\mathrm{NaCl}$-induced salt stress

\begin{tabular}{llll}
\hline Cult. & VCL treatment & Salinity $(\mathrm{mM})$ & $\mathrm{Na}^{+}(\%)$ \\
\hline "Rabab" & Treated & 0 & $0.055 \pm 0.004^{\mathrm{f}}$ \\
& & 30 & $0.099 \pm 0.013^{\mathrm{e}}$ \\
& & 60 & $0.174 \pm 0.005^{\mathrm{c}}$ \\
& Untreated & 0 & $0.055 \pm 0.002^{\mathrm{f}}$ \\
& & 30 & $0.104 \pm 0.011^{\mathrm{e}}$ \\
& & 60 & $0.187 \pm 0.004^{\mathrm{b}}$ \\
& Treated & 0 & $0.062 \pm 0.005^{\mathrm{f}}$ \\
& & 30 & $0.117 \pm 0.003^{\mathrm{d}}$ \\
& & 60 & $0.180 \pm 0.002^{\mathrm{bc}}$ \\
& & 0 & $0.064 \pm 0.004^{\mathrm{f}}$ \\
& & 30 & $0.122 \pm 0.008^{\mathrm{d}}$ \\
& & 60 & $0.205 \pm 0.008^{\mathrm{a}}$ \\
& & & 0.012 \\
\hline
\end{tabular}

Means followed by the same letter are not significantly different by the LSD Multiple Range test at $P \leq 0.05$

Majorana hortensis L. They reported that vermicompost reduced $\mathrm{Na}^{+}$content of the shoots.

CAT, APX, and SOD activity data presented in Table 6 revealed that a significant effect was observed in enzyme activity. CAT activity showed significant negative correlation with hydrogen peroxide content, in the presence of increasing salinity (Table 7). Following application of a VCL treatment, the highest activity of CAT (0.51) was found in $\mathrm{Rabab}$ under $0 \mathrm{mM} \mathrm{NaCl}$ (control conditions) (Table 6). The VCL-treated seedlings of cultivar Rababs had greater CAT activity under 60-mM NaCl-induced salt stress, but there was no significant difference in both cultivars. Results in Table 6 showed that different salinity levels exhibited variable effects on increasing APX activity and spraying VCL caused no significant changes of APX activity in response to the varying levels of $\mathrm{NaCl}$-induced salinity (Table 6). Applying the VCL-induced noticeable changes in SOD activity among both cultivars under different levels of salinity (Table 6). The VCL-treated plants of both cultivars had significantly greater SOD activity compared with non-VCL-treated plants under the highest level $(60 \mathrm{mM} \mathrm{NaCl})$ of salinity (Table 6). Garcia et al. (2012) reported that vermicompost enhanced the activity of POX resulted in a reduction of $\mathrm{H}_{2} \mathrm{O}_{2}$ content and greater conservation of membrane permeability in rice seedlings under water stress. Aremu et al. (2014) showed that increased antioxidant activities of some bulbous plants detected when VCL was applied under nutrient stress. 
Table 6 Effects of VCL treatments on the activity of CAT, APX, and SOD of pomegranate seedlings under NaCl-induced salt stress

\begin{tabular}{|c|c|c|c|c|c|}
\hline Cult. & $\begin{array}{l}\mathrm{VCL} \\
\text { treatment }\end{array}$ & $\begin{array}{l}\text { Salinity } \\
(\mathrm{mM})\end{array}$ & $\begin{array}{l}\text { Activity of CAT (U/mg } \\
\text { protein) }\end{array}$ & $\begin{array}{l}\text { Activity of APX (U/mg } \\
\text { protein) }\end{array}$ & $\begin{array}{l}\text { Activity of SOD (U/mg } \\
\text { protein) }\end{array}$ \\
\hline \multirow[t]{6}{*}{ "Rabab" } & \multirow[t]{3}{*}{ Treated } & 0 & $0.51 \pm 0.08^{\mathrm{a}}$ & $3.19 \pm 0.39^{\mathrm{b}}$ & $230.90 \pm 24.27^{\mathrm{c}}$ \\
\hline & & 30 & $0.31 \pm 0.07^{\mathrm{c}}$ & $3.71 \pm 0.43^{\mathrm{ab}}$ & $256.45 \pm 9.47^{\mathrm{ab}}$ \\
\hline & & 60 & $0.19 \pm 0.02^{\mathrm{de}}$ & $3.77 \pm 0.41^{\mathrm{ab}}$ & $204.43 \pm 6.27^{\mathrm{def}}$ \\
\hline & \multirow[t]{3}{*}{ Untreated } & 0 & $0.42 \pm 0.05^{\mathrm{b}}$ & $3.19 \pm 0.51^{\mathrm{b}}$ & $224.32 \pm 18.06^{\mathrm{cd}}$ \\
\hline & & 30 & $0.24 \pm 0.03^{\mathrm{cd}}$ & $3.89 \pm 0.35^{\mathrm{a}}$ & $185.00 \pm 6.00^{\mathrm{fg}}$ \\
\hline & & 60 & $0.13 \pm 0.03^{\text {ef }}$ & $2.20 \pm 0.27^{\mathrm{c}}$ & $176.45 \pm 10.29^{\mathrm{g}}$ \\
\hline \multirow{7}{*}{$\begin{array}{l}\text { "Malas Daneh } \\
\text { Ghermez" }\end{array}$} & \multirow[t]{3}{*}{ Treated } & 0 & $0.30 \pm 0.02^{\mathrm{c}}$ & $3.18 \pm 0.25^{\mathrm{b}}$ & $237.23 \pm 9.58^{\mathrm{bc}}$ \\
\hline & & 30 & $0.13 \pm 0.02^{\mathrm{ef}}$ & $3.89 \pm 0.23^{\mathrm{a}}$ & $262.62 \pm 12.71^{\mathrm{a}}$ \\
\hline & & 60 & $0.11 \pm 0.03^{\mathrm{f}}$ & $3.57 \pm 0.51^{\mathrm{ab}}$ & $271.29 \pm 10.79^{\mathrm{a}}$ \\
\hline & \multirow[t]{3}{*}{ Untreated } & 0 & $0.46 \pm 0.05^{\mathrm{ab}}$ & $3.20 \pm 0.30^{\mathrm{b}}$ & $221.03 \pm 8.75^{\mathrm{cde}}$ \\
\hline & & 30 & $0.19 \pm 0.02^{\mathrm{de}}$ & $3.93 \pm 0.11^{\mathrm{a}}$ & $240.51 \pm 16.04^{b c}$ \\
\hline & & 60 & $0.11 \pm 0.03^{\mathrm{f}}$ & $3.38 \pm 0.41^{\mathrm{ab}}$ & $202.21 \pm 12.83^{\text {ef }}$ \\
\hline & $\operatorname{LSD}_{(0.05)}$ & & 0.08 & 0.61 & 22.05 \\
\hline
\end{tabular}

Means followed by the same letter are not significantly different by the LSD Multiple Range test at $P \leq 0.05$

Table 7 Correlation between measured traits of pomegranate seedlings

\begin{tabular}{|c|c|c|c|c|c|c|c|c|c|c|c|c|}
\hline & 1 & 2 & 3 & 4 & 5 & 6 & 7 & 8 & 9 & 10 & 11 & 12 \\
\hline 1. Shoot dry weight & 1 & $0.76^{* *}$ & $0.86^{* *}$ & $0.90^{* *}$ & $0.81^{* *}$ & $-0.17^{\mathrm{ns}}$ & $-0.94^{* *}$ & $-0.92^{* *}$ & $-0.87^{* *}$ & $0.90^{* *}$ & $0.02^{\mathrm{ns}}$ & $0.21^{\mathrm{ns}}$ \\
\hline 2. Root dry weight & & 1 & $0.71^{* *}$ & $0.74^{* *}$ & $0.55^{* *}$ & $-0.001^{\mathrm{ns}}$ & $-0.75^{* *}$ & $-0.70^{* *}$ & $-0.61^{* *}$ & $0.58^{* *}$ & $-0.004^{\mathrm{ns}}$ & $-0.07^{\mathrm{ns}}$ \\
\hline 3. Leaf Area & & & 1 & $0.84^{* *}$ & $0.75^{* *}$ & $-0.22^{\mathrm{ns}}$ & $-0.85^{* *}$ & $-0.87^{* *}$ & $-0.88^{* *}$ & $0.77^{* *}$ & $0.05^{\mathrm{ns}}$ & $0.35^{*}$ \\
\hline 4. Chlorophyll content & & & & 1 & $0.82^{* * *}$ & $-0.30^{*}$ & $-0.95^{* *}$ & $-0.94^{* *}$ & $-0.90^{* *}$ & $0.90^{* *}$ & $-0.10^{\mathrm{ns}}$ & $0.22^{\mathrm{ns}}$ \\
\hline $\begin{array}{l}\text { 5. chlorophyll } \\
\text { fluorescence }\end{array}$ & & & & & 1 & $-0.16^{\mathrm{ns}}$ & $-0.81^{* *}$ & $-0.83^{* *}$ & $-0.83^{* *}$ & $0.86^{* *}$ & $-0.04^{\mathrm{ns}}$ & $0.35^{*}$ \\
\hline 6. Proline & & & & & & 1 & $0.27^{\mathrm{ns}}$ & $0.38^{*}$ & $0.21^{\mathrm{ns}}$ & $-0.38^{*}$ & $0.98^{\mathrm{ns}}$ & $-0.25^{\mathrm{ns}}$ \\
\hline 7. $\mathrm{H}_{2} \mathrm{O}_{2}$ & & & & & & & 1 & $0.94^{* *}$ & $0.91^{* *}$ & $-0.88^{* *}$ & $0.06^{\mathrm{ns}}$ & $-0.24^{\mathrm{ns}}$ \\
\hline 8. MDA & & & & & & & & 1 & $0.90^{* *}$ & $-0.93^{* *}$ & $-0.03^{\mathrm{ns}}$ & $-0.31^{*}$ \\
\hline 9-EL & & & & & & & & & 1 & $-0.86^{* *}$ & $-0.03^{\mathrm{ns}}$ & $-0.37^{*}$ \\
\hline 10. Activity of CAT & & & & & & & & & & 1 & $-0.05^{\mathrm{ns}}$ & $0.22^{\mathrm{ns}}$ \\
\hline 11. Activity of APX & & & & & & & & & & & 1 & $0.36^{*}$ \\
\hline 12. Activity of SOD & & & & & & & & & & & & 1 \\
\hline
\end{tabular}

*, ** and ns: significant at 0.05 and 0.01 probability levels and no significant, respectively

These results confirm the effectiveness of VCL in stimulating antioxidant mechanisms in plants.

\section{Conclusion}

The results of the present research strongly proved that foliar application of VCL improved growth parameters and physiological factors, enabling VCL-treated pomegranate seedlings to perform better. Therefore, application of VCL is recommended under salt-stress conditions.

Acknowledgements We thank all people who helped us to complete this study and wish to thank the college of agriculture, Isfahan University of Technology for allowing to conduct this study.
Open Access This article is distributed under the terms of the Creative Commons Attribution 4.0 International License (http://crea tivecommons.org/licenses/by/4.0/), which permits unrestricted use, distribution, and reproduction in any medium, provided you give appropriate credit to the original author(s) and the source, provide a link to the Creative Commons license, and indicate if changes were made.

\section{References}

Aebi H (1984) Catalase in vitro. Methods Enzymol 105:121-126 Aremu AO, Kulkarni MG, Bairu MW, Finnie JF, Van Staden J (2012) Growth stimulation effects of smoke-water and vermicompost leachate on greenhouse grown-tissue-cultured 'Williams' bananas. Plant Growth Regul 66:111-118. doi:10.1007/s10725-0119634-6 
Aremu AO, Masondo NA, Staden JV (2014) Physiological and phytochemical responses of three nutrient-stressed bulbous plants subjected to vermicompost leachate treatment. Acta Physiol Plant 36(3):721-731. doi:10.1007/s11738-013-1450-3

Arthur GD, Aremu AO, Kulkarni MG, Staden JV (2012) Vermicompost leachate alleviates deficiency of phosphorus and potassium in tomato seedlings. HortScience 47(9):1304-1307

Ashraf M (1994) Organic substances responsible for salt tolerance in Eruca sativa. Biol Plantarum 36:255-259. doi:10.1007/ BF02921095

Astaraei AR, Ivani R (2008) Effect of organic sources as foliar spray and nutrition of cowpea plant. Am Eurasian J Agric Environ Sci 3:352-356

Atiyeh RM, Subler S, Edwards CA, Bachman G, Metzger JD, Shuster W (2000) Effect of vermicomposts and composts on plant growth in horticultural container and soil. Pedobiologia 44(5):579-590. doi:10.1078/S0031-4056(04)70073-6

Ayyobi H, Olfati JA, Peyvast GA (2014) The effects of cow manure vermicompost and municipal solid waste compost on peppermint (Mentha piperita L.) in Torbat-e-Jam and Rasht regions of Iran. Int J Recycl Org Waste Agric 3:147-153. doi:10.1007/s4009

Azooz MM, Abou-Elhamd MF, Al-Fredan MA (2012) Biphasic effect of copper on growth, proline, lipid peroxidation and antioxidant enzyme activities of wheat (Triticum aestivum cv. Hasaawi) at early growing stage. Aust J Crop Sci 6:688-694

Bates LS, Waldern RP, Teare ID (1973) Rapid determination of free proline from water stress studies. Plant Soil 39:205-207. doi:10. 1007/BF00018060

Cavalcanti FR, Oliveira JT, Martins-miranda AAS, Viegas RA, Silveira JAG (2004) Superoxide dismutase, catalase and peroxidase activities do not confer protection against oxidative damage in salt-stressed cowpea leaves. New Phytol 163:563-571. doi:10.1111/j.1469-8137.2004.01139.x

Chinsamy M, Kulkarni MG, Staden JV (2013) Garden-wastevermicompost leachate alleviates salinity stress in tomato seedlings by mobilizing salt tolerance mechanisms. Plant Growth Regul 71:41-47. doi:10.1007/s10725-013-9807-6

Chinsamy M, Kulkarni MG, Staden JV (2014) Vermicompost leachate reduces temperature and water stress effects in tomato seedlings. HortScience 49(9):1183-1187

El- Khawaga AS, Zaeneldeen EMA, Yossef MA (2013) Response of three pomegranate cultivars (Punica granatum L.) to salinity stress. Middle East J Agric Res 1(1):64-75

Fathi T, Golchin A, Safikhani F (2012) Effect of drought stress and vermicompost on clary sage. Ann Biol Res 3(7):3346-3349

Garcial AC, Berbara RLL, Farias LP, Izquierdo FG, Hemandez OL, Campos RH, Castro RN (2012) Humic acids of vermicompost as an ecological pathway to increase resistance of rice seedlings to water stress. Afr J Biotechnol 11(13):3125-3134. doi:10.5897/ AJB11.1960

Hasanpour Z, Karimi HR, Mirdehghan SH (2014) Effects of salinity and water stress on echophysiological parameters and micronutrients concentration of pomegranate (Punica granatum L.). J Plant Nutr 38(5):795-807. doi:10.1080/01904167.2014.944711

Hasanuzzamaan M, Nahar K, Fujita M (2013) Plant response to salt stress and role of exogenous protectants to mitigate salt-induced damages. In: Ahmad P, Azooz MM, Prasad MNV (eds) Ecophysiology and responses of plants under salt stress. Chapter 2, Springer, New York, pp 25-87. doi:10.1007/978-14614-4747-4_2. ISBN-13: 9781461447467

Hulya Orak H (2009) Evaluation of antioxidant activity, colour and some nutritional characteristics of pomegranate (Punica granatum L.) juice and its sour concentrate processed by conventional evaporation. Int J Food Sci Nutr 60(1):1-11. doi:10.1080/ 09637480701523306
Lazcano C, Dominguez J (2010) Effects of vermicompost as a potting amendment of two commercially-grown ornamental plant species. Span J Agric Res 8(4):1260-1270

Maie Mohsen MA, Abo- Kora HA, Abeer Kassem HM (2016) Effect of vermicompost and calcium silicate to reduce the soil salinity on growth and oil determinations of Marjoram plant. Int $\mathrm{J}$ Chemtech Res 9(5):235-262

Mir M, Hassan GI, Mir A, Hassan A, Sulaimani M (2013) Effects of bio-organics and chemical fertilizers on nutrient availability and biological properties of pomegranate orchard soil. Afr J Agric Res 8(37):4623-4627

Mirzapour MH, Khoshgoftarmanesh AH (2013) Effect of soil and foliar application of iron and zinc on quantitative and qualitative yield of pomegranate. J Plant Nutr 36(1):55-66. doi:10.1080/ 01904167.2012.733049

Naeini MR, Khoshgoftarmanesh AH, Lessani H, Fallahi E (2004) Effects of sodium chloride induced salinity onmineral nutrients and soluble sugar in three commercial cultivars on pomegranate. J Plant Nutr 27:1319-1326. doi:10.1081/PLN-200025832

Naeini MR, Khoshgoftarmanesh AH, Fallahi E (2006) Partitioning of chlorine, sodium, and potassium and shoot growth of three pomegranate cultivars under different levels of salinity. J Plant Nutr 29:1835-1843. doi:10.1080/01904160600899352

Nakano Y, Asada YK (1981) Hydrogen peroxide is scavenged by ascorbate specific peroxidase in spinach chloroplasts. Photochem Photobiol 37:679-690. doi:10.1093/oxfordjournals.pcp.a076232

Nandi B, Bhandari SC, Meena RH, Meena RR (2013) Effect of vermicompost on plant growth, fruit yield and quality of pomegranate cv Ganesh. Environ Ecol 31(1A):322-324

Okhovatian-Ardakani A, Mehrabanian RM, Dehghani F, Akbarzadeh A (2010) Salt tolerance evaluation and relative comparison in cuttings of different pomegranate cultivars. Plant Soil Environ 56(4):176-185

Oliva MA, Ricon R, Zenteno E, Pinto A, Dendooven L, Gutierrez F (2008) Vermicompost rol against sodium chloride stress in the growth and photosynthesis in tamarind plantlets (Tamarindus indica L.). Gayana Bot 65(1):23-31

Ozden M, Demirel U, Kahraman A (2009) Effects of proline on antioxidant system in leaves of grapevine (Vitis vinifera L.) exposed to oxidative stress by $\mathrm{H}_{2} \mathrm{O}_{2}$. Sci Hortic 119:163-168. doi:10.1016/j.scienta.2008.07.031

Parvaiz A, Satyawati S (2008) Salt stress and phyto-biochemical responses of plants—a review. Plant Soil Environ 54:88-99

Pirseyedi S, Valizadehghan MS, Mardi M, Ghaffari MR, Mamhmoodi P, Zahravi M, Zeinalabadini M, Nekoui SMK (2010) Isolation and characterization of novel microsatellite markers in pomegranate (Punica granatum L.). Int J Mol Sci 11:2010-2016. doi:10.3390/ijms 11052010

Ramezanian A, Rahemi M, Vazifehshenas MR (2009) Effects of foliar application of calcium chloride and urea on quantitative and qualitative characteristics of pomegranate fruits. Sci Hortic 121:171-175. doi:10.1016/j.scienta.2009.01.039

Rawat JMS, Tomar YK, Rawat V (2010) Effect of stratification on seed germination and seedling performance of wild pomegranate. J Am Sci 6(5):97-99

Sallaku G, Babaj I, Kaciu S, Balliu A (2009) The influence of vermicompost on plant growth characteristics of cucumber (Cucumis sativus L.) seedlings under saline conditions. J Food Agric Environ 7(3 and 4):869-872

Schnabel G, Strittmatter G, Noga G (1998) Changes in photosynthetic electron transport in potato cultivars with different field resistance after infection with Phytophthora infestans. J Phytopathology 146(5-6):205-210. doi:10.1111/j.1439-0434.1998.tb04681.x

Velikova V, Loreto F (2005) On the relationship between isoprene emission and thermo tolerance in Phragmites ausrralis leaves 
exposed to high temperatures and during the recovery from a heat stress. Plant Cell Environ 28:318-327. doi:10.1111/j.13653040.2004.01314.x

Wang F, Zeng B, Sun Z, Zhu C (2009) Relationship between proline and $\mathrm{Hg}^{+2}$-induced oxidative stress in tolerant rice mutant. Arch Environ Contam Toxicol 56:723-731. doi:10.1007/s00244-0089226-2
Zaouaya F, Menab P, Garcia-Viguerab C, Marsa M (2012) Antioxidant activity and physico-chemical properties of Tunisian grown pomegranate (Punica granatum L.) cultivars. Ind Crops Prod 40:81-89. doi:10.1016/j.indcrop.2012.02.045 